\title{
Biocontrol ability and volatile organic compounds production as a putative mode of action of yeast strains isolated from organic grapes and rye grains
}

\author{
Renata Choińska (D) Katarzyna Piasecka-Jóźwiak • Beata Chabłowska • \\ Justyna Dumka • Aneta Lukaszewicz
}

Received: 13 November 2019/Accepted: 17 April 2020/Published online: 5 May 2020

(C) The Author(s) 2020

\begin{abstract}
The inhibiting activity of three yeast strains belonging to Pichia kudriavzevii, Pichia occidentalis, and Meyerozyma quilliermondii/Meyerozyma caribbica genera against common plant pathogens representing Mucor spp., Penicillium chrysogenum, Penicillium expansum, Aspergillus flavus, Fusarium cereals, Fusarium poae, as well as Botrytis cinerea genera was investigated. The yeast strains tested had a positive impact on growth inhibition of all target plant pathogens. The degree of inhibition was more than 50\% and varied depending on both the yeast antagonist and the mold. Ethyl esters of medium-chain fatty acids, phenylethyl alcohol, and its acetate ester prevailed among the analyzed volatile organic compounds (VOCs) emitted by yeasts in the presence of the target plant pathogens. Due to the method used, assuming no contact between the antagonist and the pathogen, the antagonistic activity of the yeast strains studied resulted mainly from the production of biologically active VOCs. Moreover, the antagonistic activity was not only restricted to a single plant pathogen but effective towards molds of different genera, making the yeast strains studied very useful for potential application in biological control.
\end{abstract}

R. Choińska $(\bowtie) \cdot$ K. Piasecka-Jóźwiak ·

B. Chabłowska · J. Dumka - A. Łukaszewicz

Department of Fermentation Technology, Institute of

Agricultural and Food Biotechnology, 36 Rakowiecka,

02-532 Warsaw, Poland

e-mail: renata.choinska@ibprs.pl
Keywords Anti-mold activity · Yeast antagonist . Biofungicide $\cdot$ Plant pathogens

\section{Introduction}

Pathogenic fungi decrease the nutritional value of food and feed. Moreover, some of them produce mycotoxins that are toxic to humans and animals. Fungal diseases and growth of pathogens are most often controlled with the use of synthetic fungicides. The main drawbacks of their use, however, include their high toxicity, ineffectiveness against certain pathogens, and problems with their registration in individual countries. The harmful effect of synthetic fungicides on the natural environment and human health has prompted the search for an eco-friendly alternative in plant disease control with particular attention to the application of microorganisms.

The use of microorganisms (yeast, yeast-like organisms, bacteria, and molds) in controlling postharvest decay of crops and fruit commodities has, actually, become one of the most frequently studied strategies for plant and harvest protection. A microbial agent having antagonistic activity against plant fungal pathogens serves as a feasible tool that allows eliminating or at least reducing synthetic fungicide usage in plant protection, by utilizing the potential of microorganisms against fungal infections/spoiling of crops and fruits during storage. Moreover, the use of 
microbial agents is consistent with consumers demand for fungicide/pesticide-free system of agriculture. Among microorganisms used as biological control agents (BCAs), many yeast species have proved highly effective owing to their widespread occurrence on plant materials, safety, and ability to colonize many environmental niches (Druvefors et al. 2005; Lahlali et al. 2011; Spadaro and Droby 2016). Important technological properties of yeast making them attractive and competitive in producing commercial BCAs, are rapid growth in relatively simple media/substrates with high efficiency, ability to survive in adverse environmental conditions, and being amenable to formulation with a long shelf-life (Chanchaichaovivat et al. 2007; Liu et al. 2014).

A number of yeast species have been identified as microbial antagonists and their inhibiting effect on mold growth and/or the production of mycotoxins, preventing their accumulation or reducing their level in the environment, has been described (Cao et al. 2013; Coehlo et al. 2007; Fiori et al. 2014). The frequently reported yeast antagonists include mainly strains belonging to the Pichia genus, e.g. Pichia caribbica, Pichia guiliermondii, Pichia membranifaciens, Wickerhamomyces anomalus (formerly Pichia anomala), and Meyerozyma gulliermondii (formerly Pichia guilliermondii) (Druvefors et al. 2005; Farkas et al. 2012; Lima et al. 2013; Parafati et al. 2015). Many studies have shown also the biocontrol ability of other yeast species, such as Rhodotorula glutinis, Rhodotorula mucilaginosa (Castoria et al. 2005; Li et al. 2011; Robiglio et al. 2011), Metschnikowia pulcherrima (Saravanakumar et al. 2008), Saccharomyces cerevisiae (Nally et al. 2015), Candida saitoana, Candida intermedia (Huang et al. 2011), Hanseniaspora uvarum (Liu et al. 2010), Hanseniaspora opuniatae (Ruiz-Moyano et al. 2016), and yeastlike Aureobasidium pullulans (black yeast) (Di Francesco et al. 2015).

The antagonistic action of yeast against pathogens can be due to different mechanisms, including competition for nutrients, colonization, production of antifungal compounds, induced systemic resistance, and mycoparasitism process (Morath et al. 2012). Saravanakumar et al. (2008) revealed that iron depletion by yeast under low iron conditions might reduce the growth of some postharvest pathogens. The following modes of action have been reported in the studies on the mechanisms of biocontrol activity of
Saccharomyces and non-Saccharomyces yeasts against fungi: competition for nutrients and space (including siderophore production), reduction in spore germination, decreased germ tube length, and inhibition of mycelial growth by volatile and diffusible metabolites (Nally et al. 2015). It has also been found that some killer toxins secreted by yeast are active not only against sensitive yeasts but also against molds (Guyard et al. 2002; Lima et al. 2013; Olstorpe and Passoth 2011). Moreover, volatile organic compounds produced by microbial antagonists are effective against many postharvest fungal pathogens (Freimoser et al. 2019). Several studies have dealt with the fungistatic activity of volatile metabolites to identify and characterize their mode of action (Pretscher et al. 2018; Wan et al. 2008; Wang et al. 2013). Volatiles are produced during diverse metabolic processes and can be classified into various chemical groups, like alcohols, esters, aldehydes, ketones, and lactones. Based on the previously reported results, it has been demonstrated that volatile metabolites are involved in the competition mechanism and play an important role in the systemic resistance against predators, parasites, and diseases (Siddiquee et al. 2012). Volatile inhibitory compounds are superior over the non-volatile ones because they can diffuse to greater distances in a structurally heterogeneous environment composed of solids, liquid, and gases (Fialho et al. 2010). The majority of studies on the use of microbial VOCs in inhibiting the growth of pathogens have been carried out under laboratory conditions. Moreover, they were mainly focused on the identification of biocontrol agents against postharvest pathogens during storage. The number of reports addressing the application of microbial VOCs under open field conditions is, however, limited (Irtwange 2006; Cortes-Barco et al. 2010; Song and Ryu 2013). The use of microbial VOCs in the open field depends on several factors, such as soil properties, microbial community, and plants exudates (Fincheira and Quiroz 2018). Another relevant issue is the manner of microbial VOCs application allowing for their efficient delivery to crop plants. The lastly reported studies focused on the reproduction of lab results in the open filed tests have shown limited protection of microbial VOCs against plant pathogens (Song and Ryu 2013). The effective exploitation of microbial VOCs still remains a challenge, and more research needs to be done in this respect (Kanchiswamy et al. 2015). 
The main objectives of this study were the selection of new yeast strains, isolated from fruit (organic grape) and rye grain, and the investigation of their antagonistic mode of action against molds, in terms of the production of volatile organic compounds. It also included the examination of the activity of the biocontrol agents selected against molds isolated from various plant environments to evaluate the broad spectrum of their activity, beneficial for further application in plant disease control.

\section{Materials and methods}

Microorganisms and culture conditions

Yeast strains used in this study were previously isolated from fruits and crops from organic farming and have been included to the Culture Collection of Industrial Microorganisms, Institute of Agricultural and Food Biotechnology (IAFB, Warsaw, Poland).

The preliminary screening for the anti-mold activity of yeast was done against molds of the Penicillium, Aspergillus, and Fusarium genera isolated from diseased grass silage and crops acc. to Piasecka-Józwiak and Chablowska (2017). Based on the results of the initial screening, yeast strains showing the best activity were selected for the study.

In the next step, the inhibition ability of the selected yeast strains was tested against new molds, isolated from infected grains representing the Mucor spp., Penicillium chrysogenum, Penicillium expansum, Aspergillus flavus, Fusarium cereals, Fusarium poae, and Botrytis cinerea genera, isolated from infested grape berries.

The three selected yeast isolates with the highest BCA (biocontrol ability) were identified, based on the D1/D2 domain sequence of the 26S rRNA gene using the primer pair NL1 and NL4 (O'Donnell 1993), as: Pichia kudriavzevii KKP 3005 (Kurtzman et al. 2008) isolated from rye grains (GeneBank accession number MK881743), Pichia occidentalis KKP 3004 isolated from organic grape (GeneBank accession number MK850405), and Meyerozyma quilliermondii (formerly $P$. guilliermondii)/Meyerozyma caribbica KKP 3003 isolated from organic grape (GeneBank accession number MK920148). The identification of molds was based on the partial sequencing of internally transcribed spacer regions and 5.8S rDNA, using ITS1 and ITS4 primers (White et al. 1990). This pair of primers has also been used in re-analyses and confirmation of yeast strains identification.

All microorganisms were stored in an atmosphere of liquid nitrogen (at $-195.8{ }^{\circ} \mathrm{C}$ ). The yeast and mold stock cultures were maintained at $4{ }^{\circ} \mathrm{C}$ on Petri dishes containing Yeast Extract Peptone Dextrose Agar (YEPD yeast extract, $10 \mathrm{~g}$; peptone, $10 \mathrm{~g}$; dextrose, $20 \mathrm{~g}$; agar, $20 \mathrm{~g}$ per liter of distilled water) and YEPD with $100 \mathrm{mM}$ citrate phosphate buffer.

The antagonistic ability of yeast was investigated in vitro on the YGC medium (yeast extract $5 \mathrm{~g}$, glucose $20 \mathrm{~g}$, chloramphenicol $0.1 \mathrm{~g}$ per liter of distilled water, agar $14.9 \mathrm{~g}$ ) (Merck).

Antagonistic activity on agar plates

The tests were conducted by simultaneous co-incubation of yeast and molds. Yeast suspensions were prepared by inoculating $100 \mathrm{~mL}$ of a YEPD broth with $1 \mathrm{~mL}$ of yeast from a culture stored in YEPD at $4{ }^{\circ} \mathrm{C}$ and agitated on a rotary shaker at $25^{\circ} \mathrm{C}$ for $24 \mathrm{~h}$. Yeast cells were pelleted by centrifugation, re-suspended in sterile distilled water, counted in the Thoma chamber, and used to inoculate the YGC agar. The yeast suspensions were adjusted to $10^{6}$ spores $/ \mathrm{mL}$ in liquid YGC agar on Petri dishes ( $9 \mathrm{~cm}$ diam). Each plate contained $10 \mathrm{~mL}$ of the medium.

Inoculums of mold were prepared from 7- to 9-day cultures grown in $\mathrm{YGC}$ at $25^{\circ} \mathrm{C}$. Spores from the cultures were collected in sterile water with $0.05 \%$ (v/ v) Tween 80 . Spore concentration was counted in the Thoma chamber and adjusted to $10^{6}$ spores $/ \mathrm{mL}$. $10 \mu \mathrm{L}$ of spore suspensions were spotted in the center of Petri dishes previously inoculated with the yeast strain tested, and incubated at $25{ }^{\circ} \mathrm{C}$. For certain molds (B. cinerea, Fusarium graminearum M26, F. poae M28, Mucor sp.), if spores were not obtained after 9-day cultivation, mycelial discs (3 mm square plug) of mycelium were placed in the center of the agar plates inoculated with the yeast. A control dish inoculated only with mold was also prepared and served as the control.

After 10 days of incubation at $25^{\circ} \mathrm{C}$, the fungal diameter was measured and growth reduction (n) was calculated compared to mold growth of the control as follows: $\% \mathrm{I}=[(\mathrm{C}-\mathrm{T}) / \mathrm{C}] \times 100$, where $\% \mathrm{I}$ represented the inhibition of colony diameter growth, $\mathrm{C}$ was diameter growth measurement in control, and $\mathrm{T}$ was 
the diameter growth of the pathogen in the presence of yeast strains.

The tests were performed in three independent experiments, each in duplicate.

Antifungal volatile compounds assay

A double Petri dish assay was used for the analysis of volatiles. To this end, a yeast suspension from a 24-h yeast culture in the YGC medium was prepared in saline water in a concentration of $10^{8}$ spores $/ \mathrm{mL}$. The yeast suspensions were adjusted to $10^{6}$ spores $/ \mathrm{mL}$ in YGC agar on Petri dishes (9 $\mathrm{cm}$ diam), containing $15 \mathrm{~mL}$ of the medium. The mold spores were harvested from the culture on the solid medium and resuspended in peptone water. Spore concentration was counted in the Thoma chamber and adjusted to $10^{5}$ spores $/ \mathrm{mL}$. $10 \mu \mathrm{L}$ of spore suspensions were spotted in the center of Petri dishes $(9 \mathrm{~cm}$ diam) containing $15 \mathrm{~mL}$ of the YGC medium. The Petri dishes were left for $90 \mathrm{~min}$ at room temperature. Afterwards, the mold-containing plate was placed over the yeast-containing plate. Both plates were immediately sealed with parafilm and incubated at $25^{\circ} \mathrm{C}$ for 5 days.

Comparable analyses were conducted on the Petri dishes containing only molds, yeasts as well as an uninoculated medium. The compounds identified in the samples containing the uninoculated medium and molds were subsequently subtracted from the analysis to show only compounds produced by the yeasts studied.

\section{Extraction and identification of volatile potentially anti-mold compounds}

Volatiles produced at the headspace above the mold cultures were collected using the solid-phase microextraction (SPME) technique (Strobel et al. 2001; Zhang and Pawliszyn 1993). After 5 days of incubation, an SPME syringe containing Carboxen-PDMS on a stable fiber $(75 \mu \mathrm{m})$ (Supelco) was gently inserted through a small hole drilled in the parafilm and exposed to the vapor phase for $45 \mathrm{~min}$ at room temperature. Then, the syringe was pulled out and inserted into the injection port of a gas chromatograph (Varian model 3800, Walnut Creek, USA) connected to an ion-trap mass spectrometer (Saturn 2000 model, Varian) for $30 \mathrm{~s}$ A DB-5MS column
$(30 \mathrm{~m} \times 0.25 \mathrm{~mm} \times 0.25 \mu \mathrm{m}, \mathrm{J} \& \mathrm{~W}$ Scientific, Folsom, CA, USA) was used for the separation of the volatiles. The oven temperature was programmed as follows: $50{ }^{\circ} \mathrm{C}$ for $1.8 \mathrm{~min}$, followed by a linear increase of $5{ }^{\circ} \mathrm{C} / \mathrm{min}$ to a maximum of $220{ }^{\circ} \mathrm{C}$ and held for $1 \mathrm{~min}$. Helium was used as the carrier gas at the rate of $1 \mathrm{~mL} / \mathrm{min}$. Injector temperature was $170{ }^{\circ} \mathrm{C}$. The manifold, GC/MS interface, and ion trap temperatures were set at $50{ }^{\circ} \mathrm{C}, 250{ }^{\circ} \mathrm{C}$, and $180{ }^{\circ} \mathrm{C}$, respectively. Mass spectra were obtained using electron impact ionization $(70 \mathrm{eV})$. Scanning was performed from $\mathrm{m} / \mathrm{z} 35$ to 200 in the electronic impact mode.

Volatile compounds were tentatively identified by comparison of their mass spectra with those available in the NIST 98 MS database.

Data analysis

The statistical analyses were conducted using the Statistica version 8 software. The significance of differences in mean values of colony's diameters were established using the one-way analysis of variance (Anova) and Tukey's post hoc tests. All analyses were performed at $\alpha=0.05$.

\section{Results and discussion}

Evaluation of in vitro antagonism

The antagonistic ability of the three yeast strains, i.e. $P$. kudriavzevii KKP $3005, \quad P$. occidentalis/Issatchenkia orientalis KKP 3004, and M. quilliermondii/Meyerozyma caribbica KKP 3003, against molds isolated from infected grains and grapes was investigated in vitro on the YGC medium. The results obtained showed that all three yeast strains studied were highly active against the target molds representing Fusarium sp., Mucor sp., B. cinerea, Penicillium sp., and Aspergillus fumigatus species (Table 1). The inhibition of mold growth, expressed as a reduction of colony growth, was higher than $50 \%$ compared to controls, while in the case of $P$. kudriavzevii KKP 3005 it was well above $80 \%$. The degree of mold inhibition varied depending on the pathogen and yeast antagonist. Among the studied yeast, M. quilliermondii/M. caribbica KKP 3003 was the least effective against Penicilium chrysogenum and Fusarium sp., 
Table 1 Antagonistic activity of yeast against mold (expressed as growth reduction $\%$, mean \pm standard error)

\begin{tabular}{llll}
\hline Molds & $\begin{array}{l}\text { Meyerozyma } \\
\text { guilliermondiil } \\
\text { M. caribbica }\end{array}$ & $\begin{array}{l}\text { Pichia } \\
\text { occidentalis }\end{array}$ & $\begin{array}{l}\text { Pichia kudriavzevii/Issatchenkia } \\
\text { orientalis }\end{array}$ \\
\hline Penicillium chrysogenum M5 & $86.5 \pm 1.96 \mathrm{a}$ & $87.7 \pm 3.35 \mathrm{a}$ & $92.9 \pm 4.43 \mathrm{~b}$ \\
Penicillium chrysogenum M24 & $85.8 \pm 2.66 \mathrm{a}$ & $91.2 \pm 1.75 \mathrm{~b}$ & $91.1 \pm 2.13 \mathrm{~b}$ \\
Penicillium chrysogenum M11 & $99.5 \pm 1.13 \mathrm{~b}$ & $100.0 \pm 0.00 \mathrm{~b}$ & $86.0 \pm 3.40 \mathrm{a}$ \\
Penicillium chrysogenum M14 & $50.2 \pm 4.73 \mathrm{a}$ & $71.4 \pm 1.28 \mathrm{~b}$ & $95.2 \pm 3.17 \mathrm{c}$ \\
Penicillium crustosum M9 & $98.6 \pm 1.54 \mathrm{c}$ & $53.2 \pm 1.81 \mathrm{a}$ & $83.7 \pm 5.35 \mathrm{~b}$ \\
Penicillium communelexpansum & $77.0 \pm 1.86 \mathrm{~b}$ & $52.1 \pm 2.28 \mathrm{a}$ & $81.5 \pm 3.27 \mathrm{c}$ \\
M6 & $66.7 \pm 3.05 \mathrm{a}$ & $81.9 \pm 2.21 \mathrm{~b}$ & $88.6 \pm 1.99 \mathrm{c}$ \\
Fusarium cereals M3 & $88.3 \pm 1.33 \mathrm{a}$ & $91.4 \pm 1.26 \mathrm{~b}$ & $91.6 \pm 2.22 \mathrm{~b}$ \\
Fusarium graminearum M25 & $76.5 \pm 2.13 \mathrm{~b}$ & $71.8 \pm 2.00 \mathrm{a}$ & $92.7 \pm 1.32 \mathrm{c}$ \\
Fusarium graminearum M26 & $79.8 \pm 1.50 \mathrm{a}$ & $89.5 \pm 1.50 \mathrm{c}$ & $85.4 \pm 1.43 \mathrm{~b}$ \\
Fusarium poae M28 & $82.7 \pm 3.79 \mathrm{a}$ & $97.8 \pm 1.88 \mathrm{c}$ & $87.8 \pm 3.23 \mathrm{~b}$ \\
Aspergillus fumigatus & $85.9 \pm 1.30 \mathrm{a}$ & $84.8 \pm 1.76 \mathrm{a}$ & $85.8 \pm 2.36 \mathrm{a}$ \\
Mucor sp. & $83.4 \pm 1.20 \mathrm{a}$ & $82.3 \pm 1.43 \mathrm{a}$ & $82.4 \pm 2.60 \mathrm{a}$ \\
Botrytis cinerea &
\end{tabular}

Different letters indicate significant differences among the mean values according to the least significant difference test $(P \leq 0.05)$

whereas P. occidentalis KKP 3004 and P. kudriavzevii/I. orientalis KKP 3005 inhibited the growth of these molds at a similar level. In the case of Mucor $\mathrm{sp}$. and $B$. cinerea, growth reduction reached about $85 \%$, and no significant differences were observed among the yeast strains studied.

Volatile organic compounds (VOCs)

The study on the inhibitory effect of the volatile compounds emitted by the yeast strains studied, as a putative mode of their action against target molds, was performed using the double Petri dish assay, assuming no contact between the antagonist and the mold. The volatile compounds collected in the gas phase were tentatively identified using SPME coupled with the GC-MS technique, which is commonly used for the analysis of volatile profiles of microorganisms (Jelen 2003; Stoppacher et al. 2010). After 5 days of incubation at $25{ }^{\circ} \mathrm{C}$, the growth of molds tested was distinctly inhibited (well above 60\%), except for $B$. cinerea, where the percentage of its growth reduction was the lowest $(\sim 11 \%)$. In the other cases, the growth reduction was similar to that observed on the YGC medium, which proves explicitly the

Table 2 Antagonistic activity of VOCs emitted by yeast strains studied against target molds (expressed as growth reduction \%, mean \pm standard error)

\begin{tabular}{llll}
\hline Molds & $\begin{array}{l}\text { Meyerozyma guilliermondii/M. } \\
\text { caribbica }\end{array}$ & $\begin{array}{l}\text { Pichia } \\
\text { occidentalis }\end{array}$ & $\begin{array}{l}\text { Pichia kudriavzevii/Issatchenkia } \\
\text { orientalis }\end{array}$ \\
\hline $\begin{array}{l}\text { Penicillium chrysogenum } \\
\quad \text { M24 }\end{array}$ & $73.3 \pm 1.31 \mathrm{a}$ & $90.5 \pm 1.45 \mathrm{~b}$ & $91.3 \pm 2.10 \mathrm{~b}$ \\
Fusarium poae M28 & $75.4 \pm 1.04 \mathrm{a}$ & $85.3 \pm 1.76 \mathrm{~b}$ & $84.8 \pm 1.32 \mathrm{~b}$ \\
Aspergillus fumigatus & $84.2 \pm 1.98 \mathrm{a}$ & $95.2 \pm 1.81 \mathrm{c}$ & $90.1 \pm 2.54 \mathrm{~b}$ \\
Mucor sp. & $64.7 \pm 1.54 \mathrm{a}$ & $72.6 \pm 1.12 \mathrm{~b}$ & $73.5 \pm 1.85 \mathrm{~b}$ \\
Botrytis cinerea & $11.1 \pm 2.20 \mathrm{a}$ & $11.8 \pm 1.06 \mathrm{a}$ & $11.2 \pm 1.25 \mathrm{a}$ \\
\hline
\end{tabular}

Different letters indicate significant differences among the mean values according to the least significant difference test $(P \leq 0.05)$ 


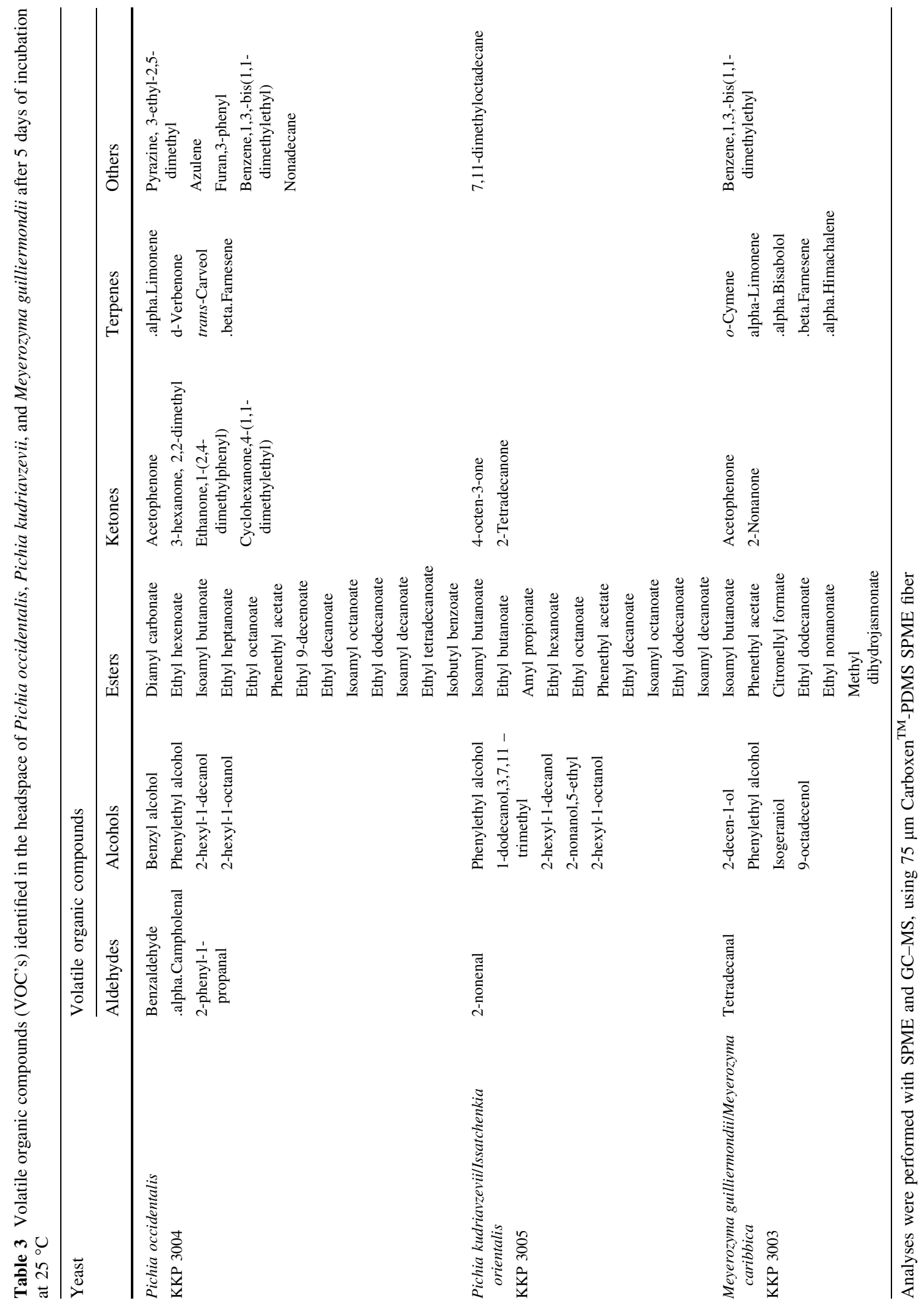




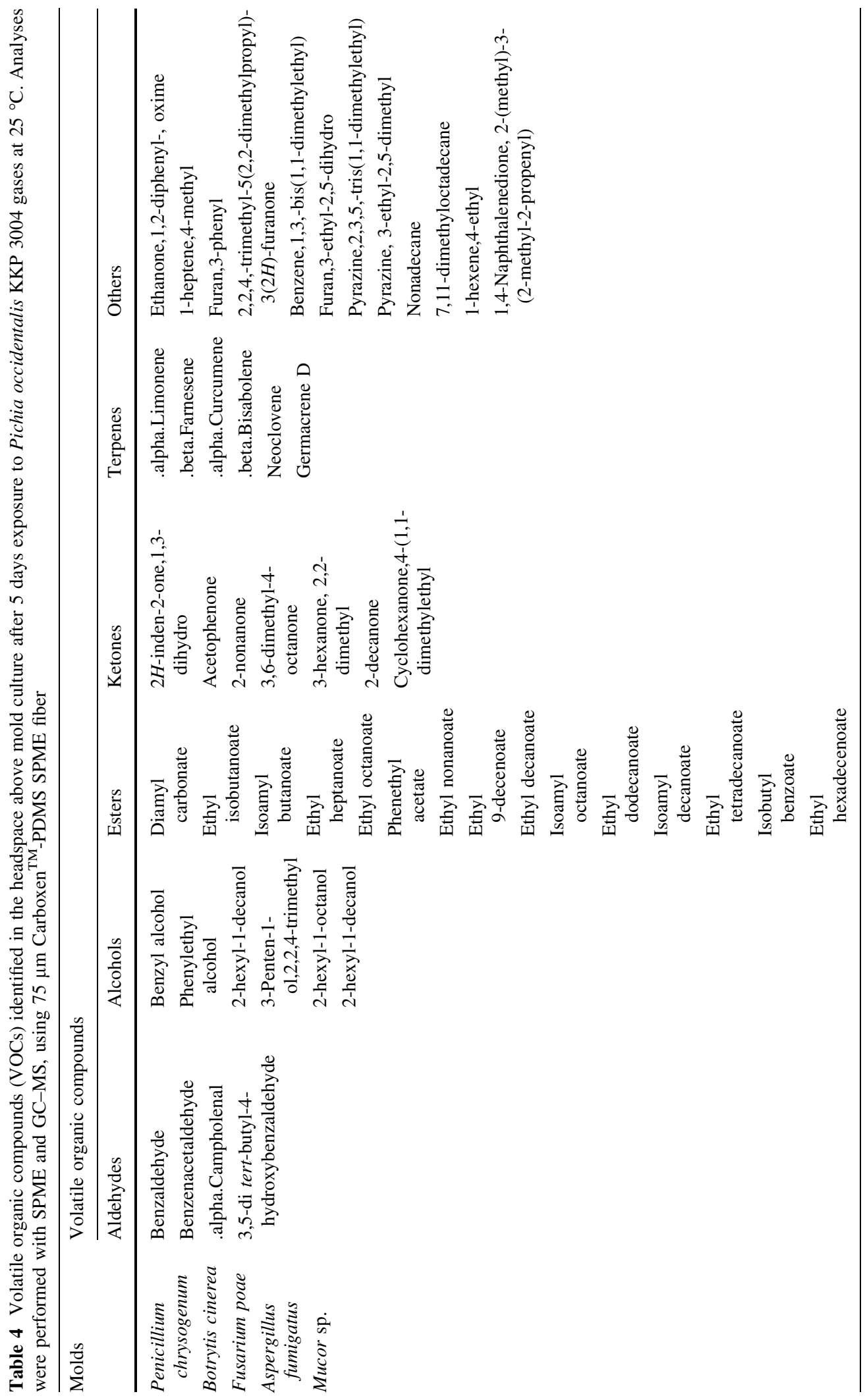


Table 5 Volatile organic compounds (VOCs) identified in the headspace above mold culture after 5 days exposure to Pichia kudriavzevii $\mathrm{KKP} 3005$ gases at $25^{\circ} \mathrm{C}$

\begin{tabular}{|c|c|c|c|c|c|c|}
\hline \multirow[t]{2}{*}{ Molds } & \multicolumn{6}{|c|}{ Volatile organic compounds } \\
\hline & Aldehydes & Alcohols & Esters & Ketones & Terpenes & Others \\
\hline $\begin{array}{l}\text { Penicillium } \\
\text { chrysogenum } \\
\text { Botrytis cinerea } \\
\text { Fusarium poae } \\
\text { Aspergillus } \\
\text { fumigatus } \\
\text { Mucor } \text { sp. }\end{array}$ & $\begin{array}{l}\text { Benzenacetaldehyde } \\
\text { 1-heptanal, 3,5,5- } \\
\text { triethyl } \\
\text { Tetradecanal }\end{array}$ & $\begin{array}{l}\text { Phenylethyl } \\
\text { alcohol } \\
\text { 2-hexyl-1- } \\
\text { decanol } \\
\text { 2-hexyl-1- } \\
\text { octanol }\end{array}$ & $\begin{array}{l}\text { Diamyl } \\
\text { carbonate } \\
\text { Ethyl } \\
\text { isobutanoate } \\
\text { Isoamyl } \\
\text { butanoate } \\
\text { Ethyl hexanoate } \\
\text { Ethyl octanoate } \\
\text { Phenethyl } \\
\text { acetate } \\
\text { Ethyl decanoate } \\
\text { Isoamyl } \\
\text { octanoate } \\
\text { Ethyl } \\
\text { dodecanoate } \\
\text { Ethyl } \\
\text { 2-heptenoate } \\
\text { Isoamyl } \\
\text { decanoate } \\
\text { Ethyl } \\
\text { dodecanoate } \\
\text { Ethyl } \\
\text { tetradecanoate }\end{array}$ & $\begin{array}{l}\text { 1,2-propanedione, } \\
\text { 1-phenyl } \\
\text { Acetophenone } \\
\text { 2-Nonanone } \\
\text { 2-decanone }\end{array}$ & Cedrene & $\begin{array}{l}\text { Tetradecane } \\
\text { 7,11- } \\
\text { dimethyloctadecane } \\
\text { 1-heptene,4-methyl } \\
\text { Benzene,1,3,-bis(1,1- } \\
\text { dimethylethyl) } \\
\text { Pyrazine, 3-ethyl-2,5- } \\
\text { dimethyl } \\
\text { Nonadecane }\end{array}$ \\
\hline
\end{tabular}

Analyses were performed with SPME and GC-MS, using $75 \mu \mathrm{m}$ Carboxen $^{\text {TM}}$-PDMS SPME fiber

antagonistic activity of VOCs released by the yeasts studied (Table 2).

The identified volatile compounds were grouped into six families, such as esters, alcohols, terpenes, ketones, aldehydes, and aromatic hydrocarbons. Table 3 presents possible compounds identified in the gas phase above the yeast cultured alone, while Tables 4, 5 and 6 summarize possible compounds identified in the headspace above molds culture after 5-day exposure to yeast gases. Ester family, including mainly ethyl esters of medium-chain fatty acids, dominated over the other groups, especially in the case of $P$. occidentalis KKP 3004 (16 compounds) and P. kudriavzevii/I. orientalis KKP 3005 (10 compounds). The emitted volatiles were strain-specific however, some of them were the same. An aromatic alcohol, phenylethyl alcohol, and its acetate ester have been identified in the case of all three yeast strains tested. The production of phenylethyl alcohol, phenylethyl acetate, and ethyl esters of the mediumchain fatty acids has been reported in other yeast species as well, e.g.: Candida tropicalis, S. cerevisiae, and P. kudriavzevii (Fiahlo et al. 2011; Koumba Kone et al. 2016). These compounds act mainly as aroma compounds, however phenylethyl alcohol and phenylethyl acetate have also been recognized as effective antifungal volatile compounds (Arrarte et al. 2017; Liu et al. 2014; Masoud and Kaltoft 2006; Meshram et al. 2017; Ting et al. 2010). Di Francesco et al. (2015) described the antagonistic activity of phenylethyl alcohol and other alcohols emitted by A. pullulans against five fruit postharvest pathogens. Results of their study showed that the identified VOCs, at a given concentration, were highly effective in suppressing the growth of pathogens. Phenylethyl alcohol was one of the identified antifungal metabolites of endophytic fungus Muscor albus, an effective biocontrol agent in controlling post-harvest diseases of fruit crops 
Table 6 Volatile organic compounds (VOCs) identified in the headspace above mold culture after 5 days exposure to Meyerozyma guilliermondii $\mathrm{KKP} 3003$ gases at $25^{\circ} \mathrm{C}$

\begin{tabular}{|c|c|c|c|c|c|c|}
\hline \multirow[t]{2}{*}{ Molds } & \multicolumn{6}{|c|}{ Volatile organic compounds } \\
\hline & Aldehydes & Alcohols & Esters & Ketones & Terpenes & Others \\
\hline $\begin{array}{l}\text { Penicillium } \\
\text { chrysogenum } \\
\text { Botrytis } \\
\text { cinerea } \\
\text { Fusarium } \\
\text { poae } \\
\text { Aspergillus } \\
\text { fumigatus } \\
\text { Mucor } \text { sp. }\end{array}$ & $\begin{array}{l}\text { 3-hydroxy-4- } \\
\text { methylbenzaldehyde } \\
\text { 1-heptanal, 3,5,5- } \\
\text { triethyl } \\
\text { 2,2-dimethyl propanal }\end{array}$ & $\begin{array}{l}\text { Phenylethyl } \\
\text { alcohol } \\
\text { 2-hexyl-1- } \\
\text { decanol } \\
\text { 2-butyl-1- } \\
\text { octanol } \\
\text { Isogeraniol } \\
\text { 1-dode- } \\
\text { canol,3,7,11- } \\
\text { trimethyl }\end{array}$ & $\begin{array}{l}\text { Diamyl } \\
\text { carbonate } \\
\text { Ethyl } \\
\text { isobutanoate } \\
\text { Isoamyl } \\
\text { butanoate } \\
\text { Isoamyl acetate } \\
\text { Ethyl octanoate } \\
\text { Phenethyl } \\
\text { acetate } \\
\text { Ethyl nonanoate } \\
\text { Ethyl } \\
\text { pentadecanoate }\end{array}$ & $\begin{array}{l}\text { Acetophenone } \\
\text { 2-Nonanone }\end{array}$ & $\begin{array}{l}\text { Neoclovene } \\
o \text {-Cymene } \\
\text { Himachalene } \\
\text {.beta.Farnesene }\end{array}$ & $\begin{array}{l}\text { Tetradecane } \\
\text { 1-heptene,4- } \\
\text { methyl } \\
\text { Benzene,1,3,- } \\
\text { bis(1,1- } \\
\text { dimethylethyl) } \\
\text { Pyrazine, 3-ethyl- } \\
\text { 2,5-dimethyl }\end{array}$ \\
\hline
\end{tabular}

Analyses were performed with SPME and GC-MS, using $75 \mu$ m Carboxen $^{\text {TM }}$-PDMS SPME fiber

(Strobel et al. 2001). Wan et al. (2008) detected phenylethyl alcohol among other volatile compounds emitted by filamentous bacteria Streptomyces platensis F-1, a potential biofumigant to control plant fungal diseases. In turn, phenylethyl acetate produced by $P$. anomala, Pichia kluyveri, and Hanseinaspora uvarum has been shown to strongly inhibit the growth of Aspergillus ochraceus (Masoud et al. 2005).

The identified volatiles emitted by $P$. occidentalis KKP 3004 and M. quilliermondii/M. caribbica KKP 3003, included also terpenes (including mono-and sesquiterpene). Some authors have indicated the biological potential of sesquiterpenes in the VOCsmediated antagonistic interactions ( $\mathrm{Li}$ et al. 2018). Limonene, a beta-bisabolene found in this study, was also detected in the volatile profiles of Trichoderma isolates exhibiting an antagonistic effect against the causal agent of barley diseases (Moya et al. 2018). Hence, the same types of volatiles could be produced by different species. However, both the production and the antimicrobial activity of VOCs varied among species and depended on several factors, including culture conditions, media type, and antagonist cell concentration.

This study showed, for the first time ever, that the VOCs produced by $P$. kudriavzevii KKP 3005, P. occidentalis/I. orientalis KKP 3004, and M. quilliermondii/M. caribbica KKP 3003, were effective against common pathogens belonging to different genera. The results obtained confirm the previous findings reported by several authors who investigated the antagonistic activity of VOCs and, therefore, they are another evidence emphasizing the essential role of VOCs in the inhibitory effect of yeast. Additionally, our study demonstrated a high efficiency of the yeasts used towards a broad spectrum of molds. It should be emphasized that, due to its limited nature, the identification technique employed allowed only the general identification of the components of the headspace above the mold cultures. Investigations performed by other authors revealed that the detection of generated volatiles and their percentage could be influenced by the analytic methodology applied and current physiological state of the antagonist (Di Francesco et al. 2015; Siddiquee et al. 2012). The widely described VOCs-mediated antagonistic action of microbials has been mostly assayed based on the observed degree of inhibition of mold growth after exposure to antagonists headspace. Thus, the production of VOCs is species-specific and, as it has already been mentioned, the antimicrobial action of volatiles should be treated as a synergistic effect with other suggested inhibitory mechanisms against the pathogen. 


\section{Conclusion}

The results of this study prove that the volatile compounds released by the three yeast strains studied acted antagonistically against molds isolated from infected crop/plants, effectively inhibiting their growth. The demonstrated activity of the selected yeast strains against plant molds well predicts their potential use in fungicidal preparations. Thus, $P$. kudriavzevii KKP 3005, P. occidentalis/I. orientalis KKP 3004, and M. quilliermondii/M. caribbica KKP 3003 can serve as promising alternatives to synthetic fungicides in the control of fungal diseases of plants. Further studies are, however, needed to develop a method for their preservation in commercial preparations.

Author contributions KPJ and RCh designed research. BCh, $\mathrm{JD}, \mathrm{A} €$, and RCh performed the experiments. RCh and KPJ analyzed the data, and drafted the manuscript. All authors read and approved the final manuscript.

\section{Compliance with ethical standards}

Conflict of interest The authors declare that they have no conflict of interest.

Open Access This article is licensed under a Creative Commons Attribution 4.0 International License, which permits use, sharing, adaptation, distribution and reproduction in any medium or format, as long as you give appropriate credit to the original author(s) and the source, provide a link to the Creative Commons licence, and indicate if changes were made. The images or other third party material in this article are included in the article's Creative Commons licence, unless indicated otherwise in a credit line to the material. If material is not included in the article's Creative Commons licence and your intended use is not permitted by statutory regulation or exceeds the permitted use, you will need to obtain permission directly from the copyright holder. To view a copy of this licence, visit http://creativecommons.org/licenses/by/4.0/.

\section{References}

Arrarte E, Garmendia G, Rossini C, Wisniewski M, Vero S (2017) Volatile organic compounds produced by Antarctic strains of Candida sake play a role in the control of postharvest pathogens of apples. Biol Control 109:14-20

Cao J, Zhang H, Yang Q, Ren R (2013) Efficacy of Pichia caribbica in controlling blue mold rot and patulin degradation in apples. Int J Food Microbiol 162(2):167-173

Castoria R, Morena V, Caputo L, Panfili G, De Curtis F, De Cicco V (2005) Effect of the biocontrol yeast Rhodotorula glutinis strain LS11 on patulin accumulation in stored apples. Phtyopathology 95:1271-1278

Chanchaichaovivat A, Ruenwongsa P, Panijpan B (2007) Screening and identification of yeast strains from fruits and vegetables: potential for biological control of postharvest chilli anthracnose (Colletotrichum capsici). Biol Control 42:326-335

Coehlo AR, Celli MG, Ono EYS, Wosiacki G, Hoffman FL, Pagnocca FC, Hirooka EY (2007) Penicillium expansum versus antagonist yeasts and patulin degradation in vitro. Braz Arch Biol Technol 50:725-733

Cortes-Barco A, Goodwin P, Hsiang T (2010) Comparison of induced resistance activated by benzothiadiazole, $(2 \mathrm{R}, 3 \mathrm{R})$ butanediol and an isoparafin mixture against anthracnose of Nicotiana benthamiana. Plant Pathol 59:643-653

Di Francesco A, Ugolini L, Lazzeri L, Mari M (2015) Production of volatile organic compounds by Aureobasidium pullulans as a potential mechanism of action against postharvest fruit pathogens. Biol Control 81:8-14

Druvefors AU, Passoth V, Schnürer J (2005) Nutrients effects on biocontrol of Penicillium roqueforti by Pichia anomala J121 during airtight storage of wheat. Appl Environ Microbiol 71:1865-1869

Farkas Z, Márki-Zay J, Kucsera J, Vágvölgyi C, Golubev W, Pfeiffer I (2012) Characterization of two different toxins of Wickerhamomyces anomalus (Pichia anomala) VKM Y-159. Acta Biol Hung 63(2):277-287

Fialho MB, Toffano L, Pedroso MP, Augusto F, Pascholati SF (2010) Volatile organic compounds produced by Saccharomyces cerevisiae inhibit the in vitro development of Guignardia citricarpa, the causal agent of citrus black spot. World J Microbiol Biotechnol 26:925-932

Fiahlo MB, Moraes MHD, Tremocoldi AR, Pascholati SF (2011) Potential of antimicrobial volatile organic compounds to control Sclerotinia sclerotiorum in bean seeds. Pesqui Agropecu Bras Bras 46(2):137-142

Fincheira P, Quiroz A (2018) Microbial volatiles as plant growth inducers. Microbiol Res 208:63-75

Fiori S, Urgeghe PP, Hammami W, Razzu S, Jaoua S, Migheli Q (2014) Biocontrol activity of four non- and low-fermenting yeast strains against Aspergillus carbonarius and their ability to remove ochratoxin A from grape juice. Int J Food Microbiol 189:45-50

Freimoser FM, Rueda-Mejia MP, Tilocca B, Migheli Q (2019) Biocontrol yeasts: mechanisms and applications. World J Microbiol Biotechnol 35:154

Guyard C, Séguy N, Cailliez JC, Drobecq H, Polonelli L, DeiCas E, Menozzi FD (2002) Characterization of a Williopsis saturnus var. mrakii high molecular weight secreted killer toxin with broad-spectrum antimicrobial activity. J Antimicrob Chemother 49(6):961-971

Huang R, Li GQ, Zhang J, Yang L, Che HJ, Jiang DH, Huang HC (2011) Control of postharvest Botrytis fruit rot of strawberry by volatile organic compounds of Candida intermedia. Phytopathology 101:859-869

Irtwange SV (2006) Application of biological control agents in pre- and postharvest operations. Agricultural Engineering International: the CIGR Ejournal. Invited overview No. 3, vol VIII 
Jeleń HH (2003) Use of solid phase microextratction (SPME) for profiling fungal volatile metabolites. Lett Appl Microbiol 36:263-267

Kanchiswamy CN, Malnoy M, Maffei ME (2015) Chemical diversity of microbial volatiles and their potential for plant growth and productivity. Front Plant Sci 6(151):1-23

Koumba Kone M, Tagro Guehi S, Durand N, Ban-Koffi L, Berthiot L, Fontana Tachon A, Brou K, Boulanger R, Monte TD (2016) Contribution of predominant yeasts to the occurrence of aroma compounds during cocoa bean fermentation. Food Res Int 89:910-917

Kurtzman CP, Robnett CJ, Basehoar-Powers E (2008) Phylogenetic relationships among species of Pichia, Issatchenkia and Williopsis determined from multigene sequence analysis, and the proposal of Barnettozyma gen. nov., Lindnera gen. nov. and Wickerhamomyces gen. nov. FEMS Yeast Res 8(6):939-954

Lahlali R, Hamadi Y, El Guilli M, Jijakli MH (2011) Efficacy assessment of Pichia guilliermondi strain Z1, a new biocontrol agent, against citrus blue mould in Morocco under the influence of temperature and relative humidity. Biol Control 56(3):217-224

Li R, Zhang H, Liu W, Zheng X (2011) Biocontrol of postharvest gray and blue mold decay of apples with Rhodotorula mucilaginosa and possible mechanisms of action. Int $\mathbf{J}$ Food Microbiol 146(2):151-156

Li N, Alfiky A, Wang W, Islam M, Nourollahi K, Liu X, Kang S (2018) Volatile compound-mediated recognition and inhibition between Trichoderma biocontrol agents and Fusarium oxysporum. Front Microbiol 9:2614

Lima JR, Gondim DMF, Oliveira JTA, Oliveira FSA, Goncalves LRB, Viana FMP (2013) Use of killer yeast in the management of postharvest papaya anthracnose. Postharvest Biol Technol 83:58-64

Liu HM, Guo JH, Cheng YJ, Liu P, Long CA, Deng BX (2010) Inhibitory activity of tea polyphenol and Hanseniaspora uvarum against Botrytis cinerea infections. Lett Appl Microbiol 51(3):258-263

Liu P, Cheng Y, Yang M, Liu Y, Chen K, Long C, Deng X (2014) Mechanism of action for 2-phenylethanol isolated from Kloeckera apiculata in control of Penicillium molds of citrus fruits. BMC Microbiol 14:242

Masoud W, Kaltoft CH (2006) The effects of yeasts involved in the fermentation of Coffea arabica in East Africa on growth and ochratoxin A (OTA) production by Aspergillus ochraceus. Int J Food Microbiol 106:229-234

Masoud W, Poll L, Jakobsen M (2005) Influence of volatile compounds produced by yeasts predominant during processing of Coffea Arabica in East Africa on growth and ochratoxin A (OTA) production by Aspergillus ochraceus. Yeast 22(14):1133-1142

Meshram V, Kapoor N, Chopra G, Saxena S (2017) Muscodor camphora, a new record from Cinnamomum camphora. Mycosphere 8(4):568-582

Morath SU, Hung R, Bennett JW (2012) Fungal volatile organic compounds: a review with emphasis on their biotechnological potential. Fungal Biol Rev 26:73-83

Moya P, Girotti JR, Toledo AV, Sisterna MN (2018) Antifungal activity of Trichoderma VOCs against Pyrenophora teres, the causal agent of barley net blotch. J Plant Prot Res 58(1):45-53
Nally MC, Pesce VM, Maturano YP, Assaf LR, Toro ME, de Figueroa LC, Vazquez F (2015) Antifungal modes of action of Saccharomyces and other biocontrol yeasts against fungi isolated from sour and grey rots. Int J Food Microbiol 204:91-100

O'Donnell K (1993) Fusarium and its near relatives. In: Reynolds DR, Taylor JW (eds) The fungal holomorph: mitotic, meiotic and pleomorphic speciation in fungal systematics. CAB International, Wallingford, pp 225-233

Olstorpe M, Passoth V (2011) Pichia anomala in grain biopreservation. Antonie van Leeuwenhoek J Microbiol 99(1):57-62

Parafati L, Vitale A, Restuccia C, Cirvilleri G (2015) Biocontrol ability and action mechanism of food-isolated yeast strains against Botrytis cinerea causing post-harvest bunch rot of table grape. Food Microbiol 47:85-92

Piasecka-Jóźwiak K, Chabłowska B (2017) Anti-mold properties of yeast strains as a biological agent for protection of grain during storage. J Res Appl Agric Eng 62(4):84-89

Pretscher J, Fischkal T, Branscheidt S, Jager L, Kahl S, Schlander M, Thines E, Claus H (2018) Yeasts from different habitats and their potential as biocontrol agents. Fermentation 4(31):3-17

Robiglio A, Sosa MC, Lutz MC, Lopes CA, Sangorrín MP (2011) Yeast biocontrol of fungal spoilage of pears stored at low temperature. Int J Food Microbiol 147(3):211-216

Ruiz-Moyano S, Martín A, Villalobos MC, Calle A, Serradilla MJ, Córdoba MG, Hernández A (2016) Yeasts isolated from figs (Ficus carica L.) as biocontrol agents of postharvest fruit diseases. Food Microbiol 57:45-53

Saravanakumar D, Ciavorella A, Spadaro D, Garibaldi A, Gullino ML (2008) Metschnikowia pulcherrima strain MACH1 outcompetes Botrytis cinerea, Alternaria alternata and Penicillium expansum in apples through iron depletion. Postharvest Biol Technol 49(1):121-128

Siddiquee S, Cheong BE, Taslima K, Kausar H, Hasan MM (2012) Separation and identification of volatile compounds from liquid cultures of Trichoderma harzianum by GC-MS using three different capillary columns. J Chromatogr Sci 50:358-367

Song GC, Ryu CM (2013) Two volatile organic compounds trigger plant self-defense against a bacterial pathogen and a sucking insect in cucumber under open field conditions. Int J Mol Sci 14:9803-9819

Spadaro D, Droby S (2016) Development of biocontrol products for postharvest diseases of fruit: the importance of elucidating the mechanisms of action of yeast antagonists. Trends Food Sci Technol 47:39-49

Stoppacher N, Kluger B, Zeilinger S, Krska R, Schuhmacher R (2010) Identification and profiling of volatile metabolites of the biocontrol fungus Trichoderma atroviride by HSSPME-GC-MS. J Microbiol Methods 81:187-193

Strobel G, Dirkse E, Sears J, Markworth C (2001) Volatile antimicrobials from Muscodor albus, a novel endophytic fungus. Microbiology 147:2943-2950

Ting ASY, Mah SW, Tee CS (2010) Identification of volatile metabolites from fungal endophytes with biocontrol potential towards Fusarium oxysporum F. sp. cubense Race 4. Am J Agric Biol Sci 5(2):177-182

Wan M, Li G, Zhang J, Jiang D, Huang HC (2008) Effect of volatile substances of Streptomyces platensis F-1 on control of plant fungal diseases. Biol Control 46:552-559 
Wang C, Wang Z, Qiao X, Li Z, Li F, Chen M, Wang Y, Huang Y, Cui H (2013) Antifungal activity of volatile organic compounds from Streptomyces alboflavus TD-1. FEMS Microbiol Lett 341:45-51

White TJ, Bruns T, Lee S, Taylor J (1990) Amplification and direct sequencing of fungal ribosomal RNA genes for phylogenetics. In: Innis MA et al (eds) PCR protocols: a guide to methods and applications. Academic Press, Inc., New York, pp 315-322
Zhang Z, Pawliszyn J (1993) Headspace solid phase microextraction. Anal Chem 65:1843-1852

Publisher's Note Springer Nature remains neutral with regard to jurisdictional claims in published maps and institutional affiliations. 